\title{
Influence of the Height of Municipal Solid Waste Landfill on the Formation of Perched Leachate Zones
}

\author{
Daniele Di Trapani ${ }^{1}$; Gaetano Di Bella²; Giorgio Mannina ${ }^{3}$; \\ Salvatore Nicosia ${ }^{4}$; and Gaspare Viviani ${ }^{5}$
}

\begin{abstract}
Waste settlement as well as consolidation phenomena, which occur inside a landfill for municipal solid waste (MSW), can cause a decrease in waste permeability. This can lead to a reduction in conveyance of the leachate drainage system. It is therefore possible that a so-called perched leachate zone will form. Such a zone is constituted by an area in the body of the landfill where the leachate is temporarily trapped and is unable to infiltrate downward. This phenomenon is influenced by many factors, which include rain infiltration rate, waste moisture and composition, landfill height, and so on. The main aim of the paper is to elucidate the role played by landfill height in the formation of perched leachate zones using a one-dimensional (1D) mathematical model. The model allows for the simulation of the percolation fluxes throughout an MSW landfill based on mass-balance equations. The results showed a different response in terms of flow rates throughout the landfill, highlighting the important role of landfill height in the formation of perched leachate zones. Landfill height influences not only the formation of perched leachate zones but also their extension throughout the body of the landfill. DOI: 10.1061/(ASCE)EE.19437870.0000950. (C) 2015 American Society of Civil Engineers.
\end{abstract}

\section{Introduction}

At present, the recovery of energy from municipal solid waste (MSW) before disposal is a rare practice adopted in only a few countries worldwide (Norbu et al. 2005). The majority of the produced MSW is still disposed of in landfills, often without any pretreatment (Babu et al. 2013; El-Fadel et al. 1997; Fellner and Brunner 2010; Slack et al. 2007). Usually, landfills for MSW disposal can be considered as large bioreactors where anaerobic processes are established, producing gaseous and liquid emissions (Imhoff et al. 2007). More specifically, biodegradable organic compounds are subjected to hydrolysis, acidification, and methanization, which produce landfill gas (LFG) composed of methane, carbon dioxide, and trace components. On the other hand, rainfall infiltration, coupled with the original moisture content of the waste, contributes to transporting pollutants and inhibitory compounds within the body of the landfill, leaching out organic and inorganic compounds. The produced leachate is generally collected by means

\footnotetext{
${ }^{1}$ Postdoctoral Fellow, Dipartimento di Ingegneria Civile, Ambientale, Aerospaziale, dei Materiali, Università degli Studi di Palermo, Viale delle Scienze, 90128 Palermo, Italy (corresponding author). E-mail: daniele .ditrapani@unipa.it

${ }^{2}$ Associate Professor, Facoltà di Ingegneria e Architettura, Università di Enna "Kore," Cittadella Universitaria, 94100 Enna, Italy. E-mail: gaetano .dibella@unikore.it

${ }^{3}$ Associate Professor, Dipartimento di Ingegneria Civile, Ambientale, Aerospaziale, dei Materiali, Università degli Studi di Palermo, Viale delle Scienze, 90128 Palermo, Italy. E-mail: giorgio.mannina@unipa.it

${ }^{4}$ Associate Professor, Dipartimento di Ingegneria Civile, Ambientale, Aerospaziale, dei Materiali, Università degli Studi di Palermo, Viale delle Scienze, 90128 Palermo, Italy. E-mail: salvatore.nicosia@unipa.it

${ }^{5}$ Professor, Dipartimento di Ingegneria Civile, Ambientale, Aerospaziale, dei Materiali, Università degli Studi di Palermo, Viale delle Scienze, 90128 Palermo, Italy. E-mail: gaspare.viviani@unipa.it

Note. This manuscript was submitted on September 1, 2014; approved on January 7, 2015; published online on February 9, 2015. Discussion period open until July 9, 2015; separate discussions must be submitted for individual papers. This paper is part of the Journal of Environmental Engineering, (C) ASCE, ISSN 0733-9372/04015013(7)/\$25.00.
}

of a drainage system at the landfill bottom, and thereafter it is either treated onsite or transferred to a wastewater-treatment plant (Sormunen et al. 2008).

Leachate production from municipal sanitary landfills is currently recognized as an important environmental issue associated with MSW management and it may be responsible for polluting local groundwater and soil (Ehrig 1983; Beaven et al. 2001). To operate landfills in a sustainable way, thus reducing their negative effects on the environment, it is important to have an understanding of their physical, chemical, and biological behavior (Fellner and Brunner 2010). In addition to biological transformations, waste settlement (Hettiarachchi et al. 2007; Babu et al. 2011) inside the landfill body might alter the (1) waste density and (2) landfill morphology, which represent the two primary factors in predicting landfill capacity as well as its hydraulic behavior (Bleiker et al. 1995; El-Fadel and Khoury 2000). Waste settlement in large landfills and the consequent increase in waste density can have a negative impact on landfill management operations due to a reduction in permeability (Powrie and Beaven 1999). The increase in the vertical strain due to MSW that has been disposed of in the upper layers, in combination with biochemical degradation, lead to a reduction in hydraulic conductivity of the landfill layers below ( $\mathrm{Wu}$ et al. 2012a, b). This behavior is of importance when referring to the formation of the so-called perched leachate zone (Koerner and Soong 2000; Fellner and Brunner 2010; Di Bella et al. 2012). Specifically, a perched leachate zone can be defined as a horizontal area in the landfill body where the leachate is temporarily trapped and is unable to infiltrate to the bottom layers, since the low hydraulic conductivity in the intermediate layers prevents the leachate from being conveyed downward as fast as it is infiltrating from the upper layers. Therefore, a perched leachate zone is a temporary phenomenon that might appear in an intermediate layer of the landfill, where a saturated horizon is confined within otherwise unsaturated waste. This phenomenon is prevalent in very high landfills where rainfall infiltration into the landfill body can be significantly higher than the water moving down toward the lower layers due to the huge decrease in effective porosity. Such a phenomenon, also emphasized by the daily clay coverage, can cause a lateral leachate 
migration (Powrie and Beaven 1999), enabling its escape from the landfill edges, influencing landfill stability with a decrease in the given site-specific factor of safety, with the possibility of contaminating external areas (Koerner and Soong 2000). In particular, previous studies analyzed the pore pressures and leachate levels in a saturated waste mass subjected to one-dimensional (1D) downward flow and infiltration into an initially unsaturated waste that remained saturated behind the wetting front (Powrie and Beaven 1999; White et al. 2011). However, the perched leachate level defined as a temporarily saturated horizon within otherwise unsaturated waste has not yet been completely elucidated. Furthermore, although the effect of landfill height on many aspects (e.g., settlement, leachate formation, gas generation, and so on) has been investigated by many researchers (e.g., Babu Sivakumar et al. 2013; White et al. 2011; Jianguo et al. 2010; Hudson et al. 2004), its influence on the formation of perched leachate zones has not been studied thoroughly.

Recently, Di Bella et al. (2012) proposed a 1D mathematical model that enables the simulation of the formation of a perched leachate zone. The proposed 1D model allows for the simulation of the percolation fluxes throughout a MSW landfill and it is based on mass-balance equations. The model showed that the formation of a perched leachate zone is strongly influenced by the initial moisture content of MSW for a given landfill height. However, the role played by landfill height in the formation of perched leachate has not been elucidated (Di Bella et al. 2012). Bearing these considerations in mind, the main aim of this paper is to gain insight about the influence of landfill height on the formation of a perched leachate zone by employing a mathematical model developed in previous studies (Di Bella et al. 2012). The final goal of this paper is to use modeling to assess the effects of landfill height as well as initial MSW moisture content. The results of the model showed that there was a different response in terms of flow rates throughout the landfill. Landfill height drastically influenced not only the formation of perched leachate zones but also their extension. In particular, the results made it possible to identify a sort of landfill height threshold below which the perched leachate zones do not appear.

\section{Methods}

\section{Model Description}

The 1D model (Di Bella et al. 2012) simulates an idealized MSW landfill taking into account the main liquid flows moving throughout the body of the solid waste. In contrast with previous studies (e.g., White et al. 2011), the model makes it possible to simulate the formation of a perched leachate zone. More specifically, the mathematical model was employed in order to quantify the role played by MSW landfill height in the formation of perched leachate zones. Fig. 1 illustrates the conceptual scheme of the model, which is employed to simulate the MSW landfill. A basic assumption of the model is that the landfill body is not subjected to variation in terms of its structure (e.g., porosity, carbon content, height, settlements, hydraulic conductivity, and so on); such a hypothesis is as much as close to the reality whenever the landfill is approaching its postoperational period.

Briefly, the model is based on mass-balance equations that allow for an evaluation of moisture content inside the landfill body, thus enabling the evaluation of perched leachate zone formation. In particular, the assumption of the model is that under unsaturated conditions, the leachate flow is only vertical, while no horizontal flow occurs.

More specifically, the simulation of unsaturated moisture flow is calculated on the basis of the Richards equation, which is highly nonlinear. The latter is obtained by coupling the vertically distributed unsaturated flow theory (Straub and Lynch 1982) with Darcy's law for an unsaturated porous medium (Childs 1967).

Referring to the numerical formulation, the solution of the mathematical model algorithms is assessed by employing an explicit finite-difference scheme of Order 1 in time and Order 2 in space. The landfill body is then divided into several layers and the formation of a perched leachate zone will only occur when the saturated moisture content is reached at any point in the landfill body. In Fig. 2, a rational scheme of model formulation and application is presented. In particular, the model takes into account the variation of MSW hydraulic conductivity with landfill height, due to waste

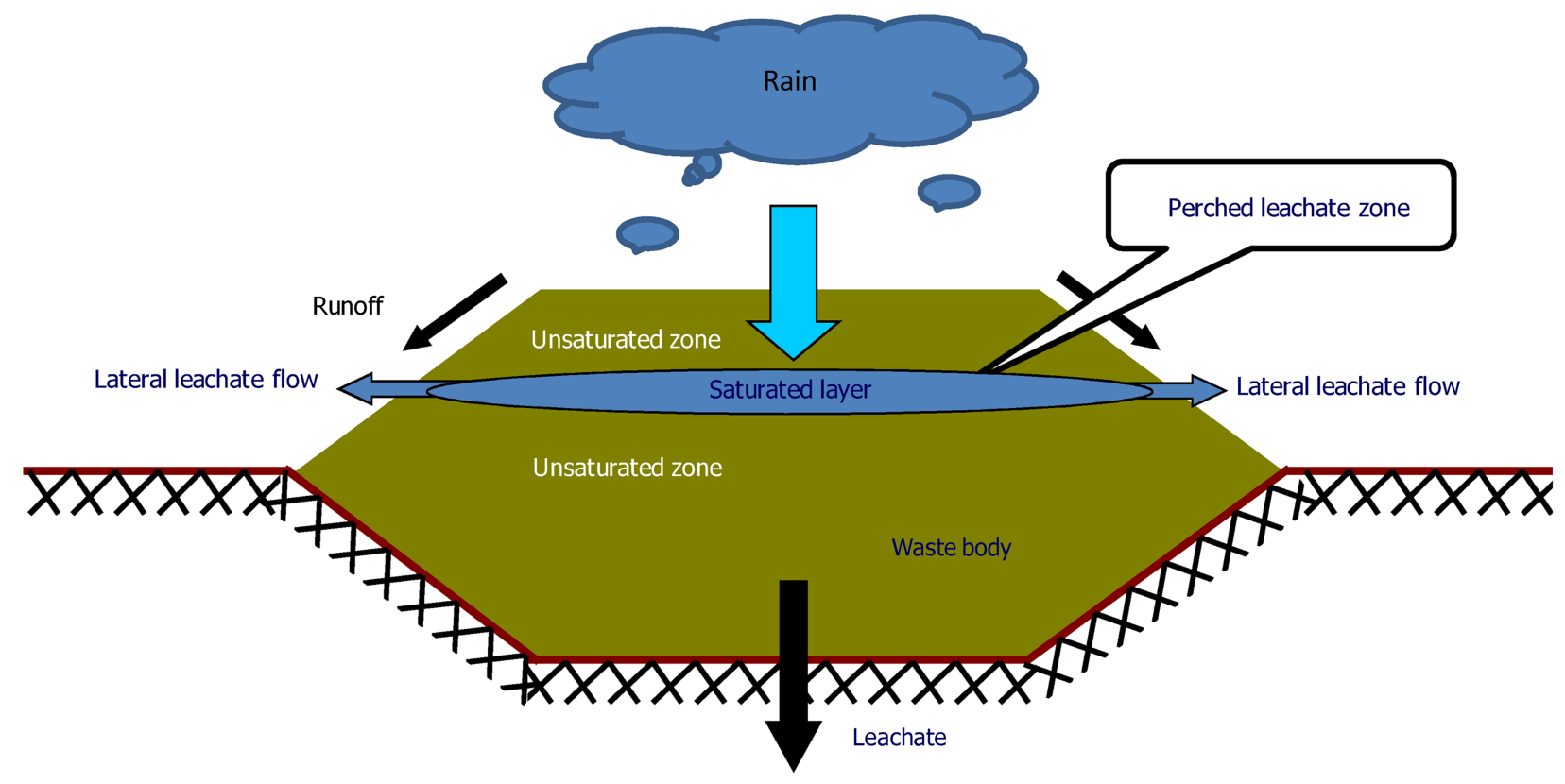

Fig. 1. Model conceptual scheme 


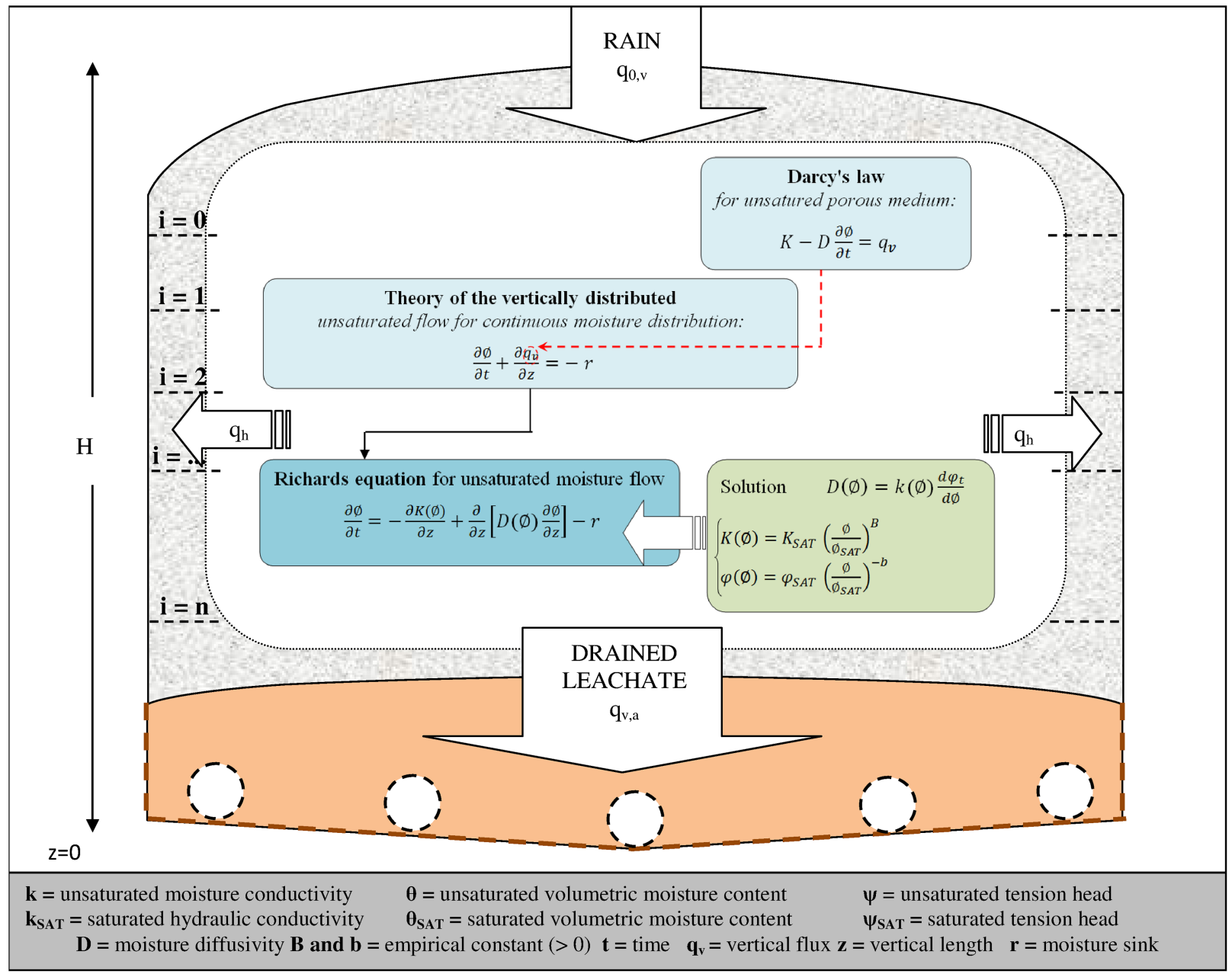

Fig. 2. Structural and rational scheme of model application

settlement and to the consequent increase in vertical strain. Therefore, the decrease of the saturated hydraulic conductivity $K_{\text {sat }}$ with landfill height can induce that, in an intermediate layer $i$, the moisture content $\theta_{i}$ reaches the saturated condition $\theta_{\text {sat }}$ and consequently the water flow infiltrating from the upper layer is higher than the corresponding $K_{\text {sat }}$, leading to the formation of a perched leachate zone. Furthermore, the excess flow that cannot be conveyed to the lower layers, which can be considered as lateral leachate flow, is obtained by means of a mass-balance equation applied to the overall waste column according to Eq. (1)

$$
\left(\theta^{k}-\theta^{k-1}\right) \times \Delta V_{\text {waste }}=\left(q_{0}^{k}-q_{v, n}^{k}-\sum_{i}^{n} q_{h}^{k}\right) \times \Delta t
$$

where $\theta^{k}=\sum \theta_{i}^{k} ; \theta^{k-1}=\sum \theta_{i}^{k-1} ; \theta^{k}=$ waste column moisture $\left(\mathrm{m}^{3} \mathrm{~m}^{-3}\right)$, expressed as the sum of the moisture of each layer $\theta_{i}^{k}$, at time $k ; \theta^{k-1}=$ waste column moisture $\left(\mathrm{m}^{3} \mathrm{~m}^{-3}\right)$, expressed as the sum of the moisture of each layer $\theta_{i}^{k-1}$, at time $k-1$; and $\Delta V_{\text {waste }}=$ elementary waste volume $\left(\mathrm{m}^{3}\right)$, with unit area and height of each equal to one of the layers. At time $k, q_{0}^{k}$ is the inlet rain flow, $q_{v, n}^{k}$ is the vertical leachate flow $\left(\mathrm{m}^{3} \mathrm{~s}^{-1}\right), q_{h}^{k}$ is the lateral leachate flow $\left(\mathrm{m}^{3} \mathrm{~s}^{-1}\right.$ ), and $i$ is the node number, ranging from 1 (superficial node) to $n$ (landfill bottom). The lateral leachate flow term $\sum q_{h}^{k}$ is assumed to be equal to zero until the moisture content is lower than the saturation value, indicating no formation of a perched leachate zone. When saturation is reached, the third term on the right-hand side of Eq. (1) will be nonnull, thus indicating the appearance of a perched leachate zone. For further details about the model, the reader is referred to the literature (Di Bella et al. 2012).

\section{Model Application}

As mentioned in the Introduction, the model was applied to semiidealized landfills characterized by different landfill heights and initial moisture content of the disposed waste. According to the employed mathematical approach, the model takes into account the dependence of the waste vertical strain on the waste wet density $\rho_{\text {wet }}$. In particular, for model application an empirical equation has been employed, derived from a real MSW landfill located in Palermo (Bellolampo's landfill). More specifically, by means of direct measurements and experimental data, the relationship between vertical stress $\sigma$ and height $z$ inside the landfill body was determined according to Eq. (2)

$$
\sigma=5.5906 \cdot z^{1.2501}
$$

This relationship has been the used to derive $K_{\text {sat }}$ and $\theta_{\text {sat }}$; Eq. (2) has been introduced into Eqs. (3) and (4) which relate the waste hydraulic properties with the vertical strain within the landfill body (e.g., Powrie and Beaven 1999; Beaven et al. 2000; Di Bella et al. 2012)

$$
\theta_{\text {sat }}=47.566 \cdot e^{-0.00179 \cdot \sigma}
$$




$$
K_{\mathrm{sat}}=10 \cdot \sigma^{-3.1}
$$

Further details referring to the direct measurements as well as to the adopted values of the model parameters are reported in Di Bella et al. (2012).

As mentioned previously, the mathematical model has been applied to four idealized MSW landfills characterized by different heights, equal to (1) $15 \mathrm{~m}$, (2) $20 \mathrm{~m}$, (3) $30 \mathrm{~m}$, and (4) $35 \mathrm{~m}$. Referring to each MSW height, in order to solve the numerical scheme, the landfill has been divided into $N$ layers of constant thickness, set equal to $1 \mathrm{~m}$. The number of layers was therefore a function of the considered landfill height. Finally, a 4-h rainfall event expressed by a triangular-shaped hyetograph has been considered (maximum intensity of rainfall, $26.05 \mathrm{~mm} \mathrm{~h}^{-1}$; total amount of water introduced into the landfill body, $51.93 \mathrm{~mm}$ ). As a basic assumption of the model application, it was hypothesized that the saturated condition at the top layer was not reached, referring to the simulated rainfall duration and initial moisture content of the MSW. Therefore, the entire rainfall flow infiltrates throughout the landfill. For each landfill height, four initial MSW moisture values $\left(\theta_{0} \theta_{\text {sat }}^{-1}\right)$ were considered, equal to (1) 0.45 , (2) 0.65 , (2) 0.80 , and (4) 0.85 , respectively. In order to obtain a better comparison superimposing similar conditions among the different simulated cases, the biological processes and/or evapotranspiration phenomena have been neglected. Furthermore, the same model simulation period ( 35 days) has been considered for the different simulated cases.

\section{Results and Discussion}

The model application enabled the calculation of vertical and lateral leachate flow, which resulted from the considered rainfall event that changed the landfill height and the initial moisture content. The model is a 1D model and therefore does not simulate the propagation of the horizontal flow. However, when a certain layer, owing to its hydraulic conductivity, reaches its maximum flow capacity, according to the model hypothesis, a perched leachate zone is implicitly constituted. The obtained results show the influence exerted by the landfill height as well as by the initial moisture content on the formation of perched leachate. Fig. 3 shows the results in terms of vertical and lateral leachate flows, per unit of horizontal landfill area, for two different landfill heights characterized by the same initial moisture content $\left(\theta_{0} \theta_{\mathrm{sat}}^{-1}=0.45\right)$. As can be observed in Fig. 3, there is a different behavior of the landfill in terms of perched leachate zone formation. Particularly, for a landfill height of $15 \mathrm{~m}$, as shown in Fig. 3(a), the whole infiltrating liquid volume deriving from the rainfall event is drained at the bottom of the landfill body. As a result, there is no formation of a perched leachate zone. Conversely, for the landfill height of $35 \mathrm{~m}$, as shown in Fig. 3(b), formation of a perched leachate zone takes place. As a result, lateral leachate flow occurs, and the vertical leachate flow wanes. An increase in vertical strain in the landfill height causes a reduction in the saturated hydraulic conductivity $K_{\text {sat }}$ [Eq. (4)]. In particular, the increase in the landfill height strongly influences the lateral leachate flow formation. As $\theta_{\text {sat }}$ decreases with the increase
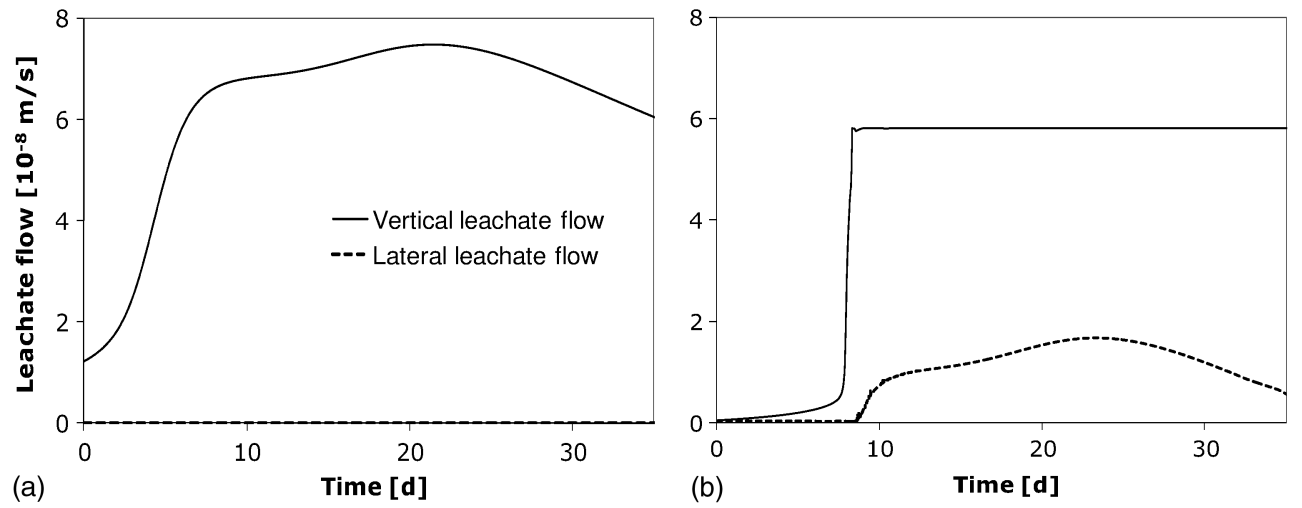

Fig. 3. Lateral and vertical leachate flow for initial moisture content $\theta_{0} \theta_{\text {sat }}^{-1}=0.45$ : (a) landfill height equal to $15 \mathrm{~m}$; (b) landfill height equal to $35 \mathrm{~m}$
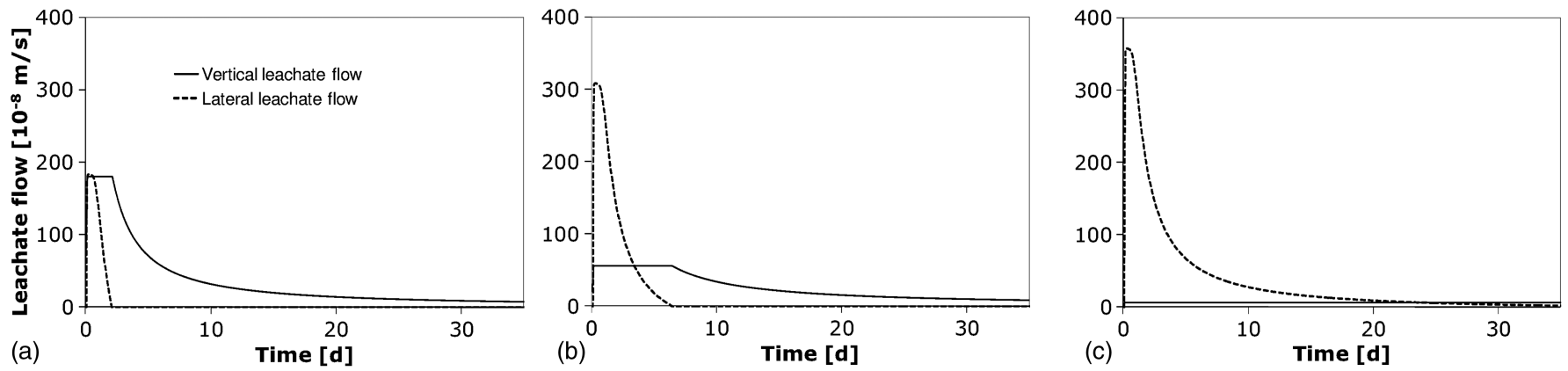

Fig. 4. Lateral and vertical leachate flow considering an initial moisture content of the following: (a) $\theta_{0} \theta_{\text {sat }}^{-1}=0.85$, landfill height equal to 15 m; (b) landfill height equal to $20 \mathrm{~m}$; (c) landfill height equal to $35 \mathrm{~m}$ 
in the landfill height, the vertical flow conveyable to the downstream layer decreases, leading to the formation of a lateral flow.

Fig. 4 shows vertical and lateral leachate flows for three different landfill heights $(15,20$, and $35 \mathrm{~m})$ with an initial moisture content equal to $85 \%$ of $\theta_{\text {sat }}$. The high value of $\theta_{\text {sat }}$ has been adopted to simulate a scenario in which the landfill is subjected to a rainfall event after another one had previously occurred.

As can be observed from Fig. 4, with this initial solid waste moisture, the occurrence of a perched leachate zone takes place for all the analyzed landfill heights. Furthermore, an increase in lateral leachate flow takes place by increasing the landfill height. Specifically, the maximum lateral leachate flow increases from 190 to $350\left(10^{-8} \mathrm{~m} \mathrm{~s}^{-1}\right)$, for an increase in landfill height from 15 to $35 \mathrm{~m}$. Such a result is consistent with the simulated physical processes. Indeed, by increasing the landfill height, a decrease in the permeability of the deeper landfill layers takes place as a result of the increase in vertical strain. Furthermore, the total model outflow (horizontal plus vertical) is approximately constant for a given initial water content and increases with increasing initial water content as the capacity of the waste for storage is reduced. The results reported in Fig. 3 differ from those of Fig. 4 due to the different storage capacities in each case.

The influence of lateral leachate flow with the initial landfill moisture content $\left(\theta_{0} \theta_{\text {sat }}^{-1}\right)$. Indeed, comparing the results characterized by a different $\theta_{0} / \theta_{\text {sat }}$ value, it turns out that the lateral leachate flow increases by two orders of magnitude regardless of the landfill height (Figs. 3 and 4). By increasing the landfill height, there is a different and opposite trend of the vertical and lateral leachate flows (Fig. 4). In particular, the vertical leachate flow decreases upon increasing the landfill height. Conversely, as a consequence, the lateral leachate flow increases upon increasing the landfill height. Such results are summarized in Table 1, where the characteristics of vertical and lateral leachate flows are reported, corresponding to different landfill heights and MSW moisture content. In Fig. 5, as an example, the location and the duration of the perched leachate zone are reported, referring to an initial $\theta_{0} \theta_{\text {sat }}^{-1}$ value equal to 0.85 and landfill height of $15,20,30$, and $35 \mathrm{~m}$, respectively. The duration and the thickness of the perched leachate zone is increasing with the landfill height; moreover, the perched leachate zone appears $10 \mathrm{~m}$ below the landfill top, almost in all the analyzed cases,

Table 1. Summary of the Vertical and Lateral Leachate Flows for the Investigated Landfill Heights and MSW Initial Moisture Contents

\begin{tabular}{|c|c|c|c|c|c|c|c|c|}
\hline \multirow{2}{*}{$\begin{array}{l}\text { Landfill } \\
\text { height (m) }\end{array}$} & \multicolumn{4}{|c|}{ Cumulative vertical flow (mm) } & \multicolumn{4}{|c|}{ Cumulative lateral flow (mm) } \\
\hline & $\theta_{0} / \theta_{\text {sat }}=45 \%$ & $\theta_{0} / \theta_{\text {sat }}=65 \%$ & $\theta_{0} / \theta_{\text {sat }}=80 \%$ & $\theta_{0} / \theta_{\text {sat }}=85 \%$ & $\theta_{0} / \theta_{\text {sat }}=45 \%$ & $\theta_{0} / \theta_{\text {sat }}=65 \%$ & $\theta_{0} / \theta_{\text {sat }}=80 \%$ & $\theta_{0} / \theta_{\text {sat }}=85 \%$ \\
\hline 15 & 214.13 & 768.62 & $1,123.75$ & $1,146.16$ & 0.00 & 0.00 & 74.71 & 195.92 \\
\hline 20 & 199.15 & 732.03 & 788.28 & 794.45 & 0.00 & 36.31 & 421.89 & 563.39 \\
\hline 30 & 190.22 & 335.79 & 344.35 & 345.26 & 0.00 & 428.50 & 865.83 & $1,013.96$ \\
\hline 35 & 151.69 & 196.34 & 200.07 & 200.36 & 38.05 & 567.71 & $1,010.06$ & $1,158.88$ \\
\hline
\end{tabular}
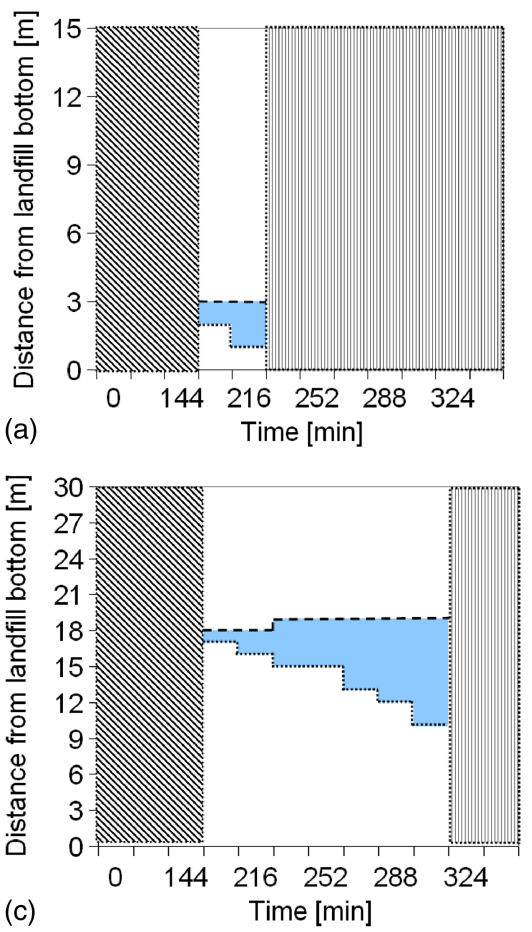

(c)

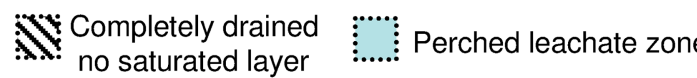

- - Upper perched leachate front
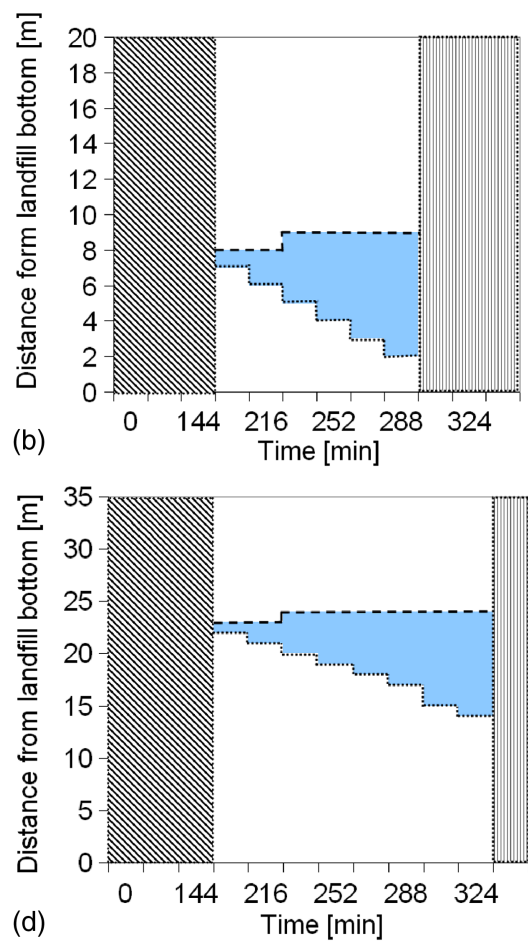

$[$ End of perched leachate zone, bottom saturated

Lower perched leachate front

Fig. 5. Location and duration of the perched leachate zone considering an initial moisture content of $\theta_{0} \theta_{\text {sat }}^{-1}=0.85$ : (a) landfill height equal to $15 \mathrm{~m}$; (b) landfill height equal to $20 \mathrm{~m}$; (c) landfill height equal to $30 \mathrm{~m}$; (d) landfill height equal to $35 \mathrm{~m}$ 


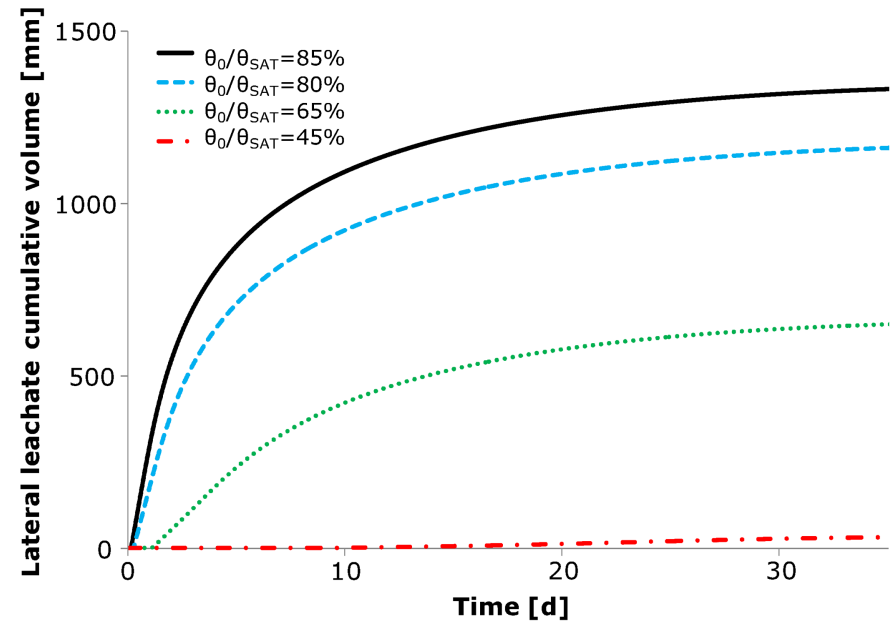

Fig. 6. Lateral leachate cumulative volume for a landfill height of $35 \mathrm{~m}$ and for different initial landfill moisture values

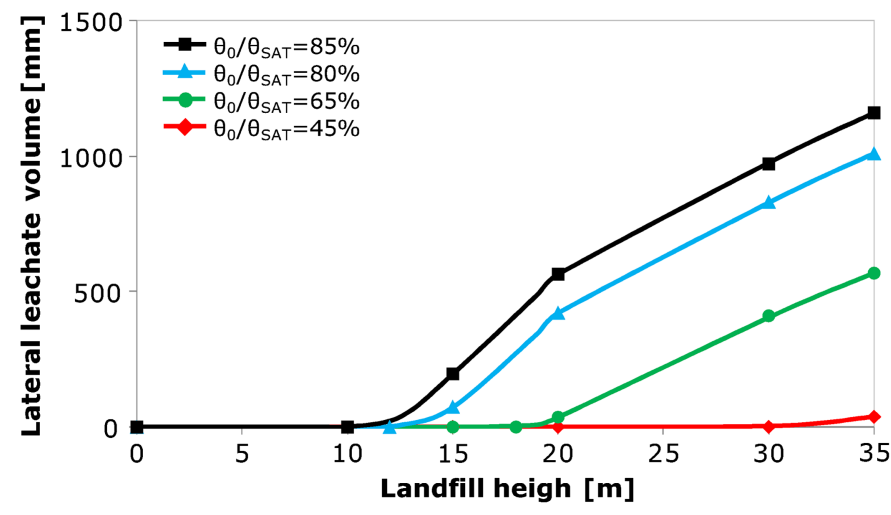

Fig. 7. Lateral leachate volume versus landfill height for different initial moisture contents

thus highlighting the potential existence of a threshold value for perched leachate formation, as better addressed in the subsequent paragraphs.

Fig. 6 shows the results in terms of cumulative curves of the lateral leachate volumes for different initial moisture content and for a landfill height of $35 \mathrm{~m}$. Fig. 6 shows how the volume of lateral leachate flow becomes significant already from an initial moisture content ratio equal to 0.65 , which represents the usual moisture content of MSW disposed of in landfills. Lateral flow, for the considered landfill heights, occurs more rapidly when the initial moisture content of the landfill body is higher.

In Fig. 7, the total lateral volume as a function of landfill height and initial MSW moisture content is reported. Fig. 7 shows the influence that both the initial moisture content and the landfill height have on perched leachate formation.

Regarding Fig. 7 , for $\theta_{0} \theta_{\text {sat }}^{-1}$ equal to 0.85 , no perched leachate formation occurs when the landfill height is lower than about $10 \mathrm{~m}$. This is consistent with the simulated phenomena. Upon increasing the waste density with the landfill height, an effect of waste settlement, a reduction in hydraulic conductivity takes place (Powrie and Beaven 1999). Thus, the upper layers of the landfill body are capable of draining a liquid volume that decreases with landfill height. As a consequence, it is possible to establish a sort of landfill threshold height below which no perched leachate occurs, and such a value is strongly influenced by the initial moisture content of waste, by means of a nonproportional relationship.

\section{Conclusions}

The percolation of leachate through a MSW landfill was simulated by means of a simplified 1D model based on mass-balance equations. The model was applied to a semiidealized landfill characterized by four different landfill heights [namely (1) $15 \mathrm{~m}$, (2) $20 \mathrm{~m}$, (3) $30 \mathrm{~m}$, and (4) $35 \mathrm{~m}$. Synthetic triangular hyetographs were adopted for the simulation of the rainfall, which is the main input for the simulation of the MSW leachate flow. For each landfill height, four different initial MSW moisture contents were taken into account. The results confirmed the important role played by landfill height on the formation of lateral leachate flow and they also showed the influence of the initial MSW moisture content on the potential formation of perched leachate zones. Moreover, the results showed that lateral leachate flow is as high as the increase in the initial moisture content. Upon increasing the initial moisture content of MSW, saturation is achieved at the beginning of the rain event. Such a fact leads to a reduction in the vertical leachate flow because leachate flows in a saturated medium result in an increase in the perched leachate volume. Finally, the model results showed that a sort of critical landfill height exists, below which the perched leachate zone does not exist.

\section{References}

Babu Sivakumar, G. L., Chouksey, S. K., and Reddy, K. R. (2013). "Approach for the use of MSW settlement predictions in the assessment of landfill capacity based on reliability analysis." Waste Manage., 33(10), 2029-2034.

Babu Sivakumar, G. L., Reddy, K. R., and Chouksey, S. K. (2011). "Parametric study of MSW landfill settlement model." Waste Manage., 31(6), 1222-1231.

Beaven, R., Knox, K., and Croft, B. (2001). "Operation of leachate recirculation trial in a landfill test cell." Proc., Eighth Int. Waste Management and Landfill Symp., T. H. Sardinia, R. Christensen, R. Cossu, and R. Stegmann, eds., 595-604.

Beaven, R. P., Powrie, W., and Hudson, A. P. (2000). "Development of sustainable landfill practices and engineering landfill technology." Final Rep. to the Engineering and Physical Sciences Research Council, Dept. of Civil and Environmental Engineering, Univ. of Southampton, Southampton, U.K.

Bleiker, D. E., Farquhar, G., and McBean, E. (1995). "Landfill settlement and the impact on site capacity and refuse hydraulic conductivity." Waste Manage., 13(6), 533-554.

Childs, E. C. (1967). Soil moisture theory, advances in hydroscience, V. T. Chow, ed., Academic Press, New York.

Di Bella, G., Di Trapani, D., Mannina, G., and Viviani, G. (2012). "Modeling of perched leachate zone formation in municipal solid waste landfills." Waste Manage., 32(3), 456-462.

Ehrig, H.-J. (1983). "Quality and quantity of sanitary landfill leachate." Waste Manage. Res., 1(1), 53-68.

El-Fadel, M., Findikakis, A. N., and Leckie, J. O. (1997). "Modeling leachate generation and transport in solid waste landfills." Environ. Technol., 18(7), 669-686.

El-Fadel, M., and Khoury, R. (2000). "Modeling settlement in MSW landfills: A critical review." Crit. Rev. Environ. Sci. Technol., 30(3), 327-361.

Fellner, J., and Brunner, P. H. (2010). "Modeling leachate generation from MSW landfills by a 2-dimensional 2-domain approach." Waste Manage., 30(11), 2084-2095.

Hettiarachchi, C. H., Meegoda, J. N., Tavantzis, J., and Hettiaratchi, P. (2007). "Numerical model to predict settlements coupled with landfill 
gas pressure in bioreactor landfills.” J. Hazard. Mater., 139(3), 514-522.

Hudson, A. P., White, J. K., Beaven, R. P., and Powrie, W. (2004). "Modelling the compression behaviour of landfilled domestic waste." Waste Manage., 24(3), 259-269.

Imhoff, P. T., et al. (2007). "Review of state of the art methods for measuring water in landfills." Waste Manage., 27(6), 729-745.

Jianguo, J., Yong, Y., Shihui, Y., Bin, Y., and Chang, Z. (2010). "Effects of leachate accumulation on landfill stability in humid regions of China." Waste Manage., 30(5), 848-855.

Koerner, R. M., and Soong, T. Y. (2000). "Leachate in landfills: The stability issues." Geotext. Geomembr., 18(5), 293-309.

Norbu, T., Visvanathan, C., and Basnayake, B. (2005). "Pretreatment of municipal solid waste prior to landfilling." Waste Manage., 25(10), 997-1003.

Powrie, W., and Beaven, R. P. (1999). "Hydraulic properties of household waste and implications for liquid flow in landfills." Proc. Inst. Civ. Eng. Geotech. Eng., 137(4), 235-247.
Slack, R. J., Gronow, J. R., Hall, D. H., and Voulvoulis, N. (2007). "Household hazardous waste disposal to landfill: Using LandSim to model leachate migration." Environ. Pollut., 146(2), 501-509.

Sormunen, K., Ettala, M., and Rintala, J. (2008). "Internal leachate quality in a municipal solid waste landfill: Vertical, horizontal and temporal variation and impacts of leachate recirculation." J. Hazard. Mater., 160(2-3), 601-607.

Straub, W. A., and Lynch, D. R. (1982). "Models of landfill leaching. Moisture flow and inorganic strength." J. Environ. Eng., 108.

White, J. K., Beaven, R. P., Powrie, W., and Knox, K. (2011). "Leachate recirculation in a landfill: Some insights obtained from the development of a simple 1-D model." Waste Manage., 31(6), 1210-1221.

Wu, H., Chen, T., Wang, H., and Lu, W. (2012a). "Field air permeability and hydraulic conductivity of landfilled municipal solid waste in China." J. Environ. Manage., 98, 15-22.

Wu, H., Wang, H., Zhao, Y., Chen, T., and Lu, W. (2012b). "Evolution of unsaturated hydraulic properties of municipal solid waste with landfill depth and age." Waste Manage., 32(3), 463-470. 